\title{
Optimization of Decision Process in a Theory of Financial Instability
}

\author{
Konrad Raczkowski \\ Pawel Wlodkowic University College \\ Kilinskiego 12, 09-402 Plock, Poland \\ E-mail: raczkowski.konrad@gmail.com
}

Received: August 3, $2011 \quad$ Accepted: August 22, $2011 \quad$ doi:10.5430/rwe.v2n2p43

\begin{abstract}
A theory of financial instability, positively verified through adverse consequences of the global financial crisis that started in 2007, demonstrates the significance put on adequate decision making in present age. Thus, optimization of operations in this respect applies to providing suitable frameworks for supervision and functioning of financial markets which may be more predictable and secure for individual stakeholders.
\end{abstract}

Keywords: Financial Instability, Optimization, Decisions, Financial Markets, Supervision.

\section{Instead of the Introduction - The Largest Speculative Bubble Worldwide}

The global financial crisis which surfaced at the end of the first decade in the 21st century on the US subprime mortgage market, had its origins in 2001. Back at that time the dotcom bubble, inflated by the investment banks over preceding years (since the second half of 1990s), finally burst. The crash and consequent losses estimated at USD 5 trillion caused the collapse of the NY stock exchange with regard to internet companies. The investigation conducted by Attorney General Eliot Spitzer showed that the market slump itself did not occur by pure chance but was an outcome of premeditated operations carried out by the largest financial institutions. The investment banks intentionally promoted these internet companies even though they knew that the companies would fail (explaining later that it was a common practice). The investigation, completed in December 2002, led to the settlement which obliged ten of the US top investment firms involved to pay a total of USD 1.5 billion in penalties and commit themselves to reforming the practices used to make money by unfair means (Atkinson, Ezell, Andes, Castro, Bennett, 2010).

In the aftermath of the crisis in the US internet market, income tax was reduced and the FED lowered interest rates (from $6.5 \%$ in 2000 to $1.75 \%$ in 2004) (White, 2007) and therefore made it possible for the banks to extend mortgages at a low interest rate for housing. In this way, the self-propelling spiral driving economic prosperity was put in motion, however this situation could not continue indefinitely. The demand for housing was on the rise due to easy access to mortgages and the granting of mortgages on a massive scale, which was accompanied by rising house prices. The bankers assumed that real estate would maintain its value as home price appreciation in the US had seemed an unstoppable trend since WW2. For these reasons the forecast models for risk analysis of this investment portfolio did not practically consider any risk with regard to default in payment of loans by borrowers.

In 1996-2006 the housing prices soared as much as to double in the US. The value of subprime mortgages in the funds increased from USD 30 billion per annum to almost USD 600 billion. The largest subprime mortgage originator in the US market was Countrywide Financial Corp. which from a generated trading at USD 11 billion posted USD 4 billion profit (from which almost half stemmed from subprime mortgages) (Mason, 2010). Whereas the largest underwriter of subprime mortgages was Lehman Brothers (over USD 106.4 trillion in 2005-2006) (Dunbar, Donald, 2009).

\section{$<$ Figure 1 about here $>$}

At the time of robust demand for mortgages the investment banks borrowed such large amounts as to enable them to create a growing number of increasingly complicated derivatives. A borrower was easily granted a mortgage on preferential conditions, i.e. at low, fixed and introductory or "teaser" rates which were supposed to be in effect for just a short period (usually 2-3 years), at which point the rate was to climb, reaching a floating rate as a result of an increase in real estate prices in the market which then allowed for subsequent refinancing mortgage. The banks took it for granted that subprime mortgages are extended for borrowers with lower credit rating (having less income) which did not guarantee payment at an increased rate - without a necessity to refinance. Both the banks as well as rating agencies were misled with a belief that was fed by constantly rising home prices. On the other hand such a conviction could serve as a credible explanation for a meltdown of this market segment, while the real reasons behind such dodgy activities 
performed by the banks were fuelled by an urge to boost their own short-term gains by taking on maximum risk.

The subprime market operated in the following way: housing prices climbed, so mortgages were refinanced at a lower interest rate because as the house became worth more it was followed by a lower rate mortgage and a mortgage was again refinanced until a borrower became the owner of the property, paying exceptionally low interests over the whole period of the mortgage (Goodhart, 2009).

On top of that the banks started to issue securities called collateralized mortgage obligations (CMOs) on a large scale (as the major type of an asset-backed security) pursuant to procedures defined in 1983 by the First Boston bank and Salomon Brothers. Thus, the banks disposed of risky mortgages, shifting the default risk of home mortgages and all the related threats to an investor.

The mortgage market, thus, spiralled out of the banks control. First, most of mortgages were granted through advisors/intermediaries (almost 60\%) who after concluding the agreement were released from any responsibility for further consequences arising from signing the agreement. Second, banks disposing the collateralized mortgage obligations were not interested in thorough vetting of potential borrowers' economic credibility (Sikorka, Wiatrak, 2011).

At the time when the market operated in a stabile manner without any fluctuations, making profit on mortgage-financed real estate was widespread. The whole mechanism, however, ceased to operate in the wake of the US economic downturn in 2006-2007. To stave off the inflation risk the Fed was forced to increase the interest rates, which led to insolvency of borrowers, thus shifting the risk of payment onto investors. The investors mostly included investment funds, banks, insurance companies, or other companies which purchased securities in this market segment. Many of these institutions plunged into multi million debts and to avoid going bust they had to incur loans from other banks to discharge their liabilities.

The value of the sector was high as the fuelled demand for mortgage enhanced the value of the real estate market and the rating agencies often conferred the highest rating "AAA" on this type of securities. When a large portion of borrowers were unable to pay off their liabilities, there was a decline in financial instruments backed by loans. An enforced securitization of mortgages (selling off the whole mortgage to external entities or its portion backed by income from mortgage) spread the risk onto the global markets, which in turn caused a global liquidity crisis (triggered by lack of possibilities to localize the risk underlying mortgage-backed securities) (Benedyczuk, Boruch, 2009).

In most cases the crisis most deeply affected ordinary people of the specific country or region where devaluation took place. In the global crisis of the $21^{\text {st }}$ century as many as nine of the largest bankruptcies were ranked on the list of 22 most spectacular bankruptcies ever (they were on top of the list) (Ross, 2011). Whereas in terms of value, the total value of nine bankruptcies prompted by the ramifications of the financial crisis in 2007 amounted to over USD 1.3 trillion (USD 1,347.9 million) and represented almost 72\% value of 22 largest bankruptcies ever altogether.

Solely the problems outlined which stem from the latest financial crisis allow for formulating the hypothesis that in the theory of financial instability decision processes may be optimized due to new architecture for oversight across the global financial system. Its objective would be, above all, safeguarding stakeholders of the financial markets from unfair practices, and on occasion from activities, criminal in their character, deliberately devised.

\section{Minsky's Theory of Financial Instability}

The theory of financial instability developed by Hyman Minsky (1919-1996) in 1982 represents one of hypothesis to elucidate economic crises triggered by financial crises. He argues that an economic growth evolves, in a natural way, into disturbance of financial balance. It is made possible by use of three types of financing; so called hedge finance (possibility of payment of principal and interests from possessed non-financial assets), speculative finance (capacity to pay off interests without principal; a type of financing exploited by governments of given states), and Ponzi finance (so-called Ponzi scheme where a borrower is not able to pay off interests and principal, and is then compelled to rely on refinancing, incurring a new debt - which, all the more, cannot be paid off). Under the Ponzi scheme its organizer recruits new investors, while within the classical pyramid scheme investors recruit new investors (Dettro, 2008). In the course of operations on the financial markets, according to Minsky's theory, the following phases of credit cycle occur, beginning from an initial shock, through boom, euphoria and profit taking, and finally panic. The final stage takes over when hedge finance converts into a Ponzi pyramid scheme (Kluza, Cholewinski, 2010).

Panic, as the final credit cycle (just observed since 2007 on subprime mortgage market in the United States), urges to scale down securitized credits. In the meantime escalating caution combined with a fall in mutual confidence leads to freezing the inter-bank market, and banks alone impose stringent restrictions on granting credits, simultaneously increasing costs of obtaining credits. At that time stakeholders who used financing based on the Ponzi scheme, observing 
risk related to lack of possibilities to regain receivables, resell owned assets which ultimately brings about collapse of their prices (resulting from herd behaviour of stakeholders)

$<$ Figure 2 about here $>$

It is the collapse of the market which has an adverse impact on the whole economy. A level of investment as well as consumption demand declines, causing decreased GDP, reduction of employment, increased saving habits among individuals. Furthermore, the black economy is boosted while the state budget generates smaller revenues, which then results in further economic slowdown and even recession (Kluza, Cholewinski, 2010).

The time when the financial pyramid breaks down as a consequence of numerous speculative operations has come to be known as a "Minsky moment". It proves impossible to maintain a banking system without government intervention as the negative structure of financial markets is too robust to be overcome by individual financial institutions (Whallen, 2007).

It may be indicated that Hyman Minsky's theory of financial instability has been positively evidenced through negative implications of the recent financial slump in 2007. Effective financial control, and thus appropriate state institutional supervision is necessary to the whole process of safeguarding financial markets.

According to Minsky, the key role in this process should be played by the central bank through maintaining liquidity on financial markets (a policy of interest rates is regarded as minor in this process), and appropriate regulation of the entire financial sector (Kluza, Cholewinski, 2010).

\section{European Optimization Processes with Regard to Prevention of Financial Instability}

In presenting the issues of optimization of decision processes designed to mitigate the risk of financial instability it is necessary to make reference to the EU member states which formed the first integration group to undertake the measures in this respect. Perceiving the unstable situation of interconnected financial systems, the states of the European Community, with the assistance of Commission President Jose Manuel Barroso, established in November 2008 the so-called high level expert group on EU financial supervision, composed of eight representatives and chaired by Jacque de Larosière. The group's report published in 2009 constituted the basis for the European Commission to set out new proposals of solutions for European financial supervision. In its Communication on Financial Supervision in Europe published in May 2009 the European Commission proposed (in conformity with recommendations made by the high level expert group) establishment of a supervisory framework for the European financial market, based on two pillars, intended to enhance optimization of decision processes in respect of financial instability:

$>$ Macro-prudential supervision -conducted by the European Systemic Risk Board ERRS charged with monitoring and assessing potential macroeconomic threats in the financial system (providing an early warning of system-wide risks, issuing recommendations for scope and direction of actions in order to tackle these risks). The Board is shored up in its administrative, logistic, statistics and information operations by the European Central Bank - ECB (also taking advantage of expertise of national central banks and supervising institution) while retaining its autonomy. In view of the significant responsibility of the ERRS it is the responsibility of the ECB president to supervise this organ (at least the for the first part of its five year term) (Regulation OJ L 331/1, 2010),

$>$ Micro-prudential supervision - by the European System of Financial Supervisors - ESFS (Regulation COM 503, 2009) covering a network of national financing supervisors in the EU member states together with three new central supervising institutions: European Banking Authority - EBA, European Securities and Markets Authority - ESMA and European Insurance and Occupational Pensions Authority - EIOPA (Directive 0006 COD, 2011).

In this way the European System of Financial Supervisors (ESNF) began to operate in January 2011 embracing six major areas - of the community as well as domestic ones (Regulation OJ L 331/1, 2010, OJ L 33/12, 2010, OJ L 331/15, 2010).

\section{$<$ Figure 3 about here $>$}

Moreover, the European Supervisory Authorities - ESAs, replacing the existing committees operating in London, Frankfurt and Paris, have a unified structure comprised of a Board of Supervisors, Management Board, Chairperson, Executive Director and Board of Appeal, common for three institutions. In all institutions the key obligations and decision making are vested in the Board of Supervisors. The Board is composed of representatives of all national supervisory authorities (with right of the voice) and one representative, without the right of the voice, from: the European Commission, European Systemic Risk Board as well as representatives of two remaining supervisory 
authorities.

It should be noted that major responsibilities of the European Supervisory Authorities are as follows:

$>$ Establish high quality consistent supervisory practices and standards for the financial market in the EU (including those related to regulation projects and executive technical standards),

$>$ Participate in implementation and application of legally binding EU acts (setting up a common supervisory organizational culture and counteracting regulatory arbitrage, conducting mediation and settlement of disputes between relevant organs, actions in situations of increased risk and extraordinary cases, ensuring coherent operations carried out by boards of supervisory authorities),

$>$ Maintain cooperation with the Systemic Risk Board, notably with regard to appropriate exchange of information and ensure a coordinated response in connection with recommendations and warnings by the ERRS,

$>$ Facilitate communication and delegation of tasks and responsibilities to relevant supervisory authorities,

$>$ Permanent monitoring of financial markets with regard to appropriate competence,

$>$ Analyse mutual assessments of relevant supervisory authorities as well as analyse economic markets,

$>$ Enhance security of stakeholders/clients of financial markets (each supervisory authority to the extent of their relevant own competence),

$>$ Measure systemic risk on a regular basis and develop and coordinate recovery schemes - in the case of the European Banking Authority and the European Securities Authority - devising methods for undertaking recovery proceedings for stakeholders on financial markets or failing institutions; evaluating necessary financing resources (ESFS, 2011).

The European Supervisory Authorities enjoy the support and cooperation of the Committee on the Global Financial System - CGFS as one of the Committees of the Bank for International Settlements.

Current tasks of the Committee focus on ensuring stability in financial as well as monetary fields while addressing threats to the global financial system, and include as follows:

$>$ Identifying and assessing potential threats in global financing markets (constant monitoring, risk analysis, assessment of macroeconomic situations),

$>$ Furthering the understanding of trends and mechanisms occurring in current financial markets (implications for central banks, responsibility),

$>$ Pursuing the policy of recommendations and good practices through continued exchange of information, shoring up resilient and responsible financial markets in promoting suitable organizational and legal solutions (Mitrega-Niestrój, 2011).

Thus, it is evident that it embraces a wide spectrum of optimization actions intended to finally provide a more effective opportunity for assessing risk of financial instability and leading to effective regulations in this respect.

\section{Conclusions}

When analysing optimization of decision processes in the theory of financial instability, it is necessary to take into account the fact that optimal decisions, from the perspective of stakeholders in present-day financial markets operating solely to boost capitalization of possessed assets (often of speculative nature), are not always in compliance with law and may engender catastrophic effects. As a result of the financial slump in 2007, the largest in history, almost 30 million people lost their jobs (Trends econometric, 2011), and capitalization of global financial markets in the crunch of the collapse plunged from over USD 62 trillion in October 2007 to USD 27 trillion in February 2009 (Index, 2011).

It seems that the issue of regulating the whole segment of the financial market constitutes a significant process of optimization changes which may further safeguard individual countries or regions against an economic slump triggered by increasing risk of financial instability. Therefore, it is certain that in a short-term or medium-term perspective other countries will also revise their national systems of financial supervision and substantially modify them. 


\section{References}

Atkinson R. D., Ezell S. J., Andes S. M., Castro D. D., Bennett R. (2010). The internet economy 25 years after.com. Transforming Commerce \& Life, The Information Technology \& Innovation Foundation, Washington, March, 7.

Benedyczuk, E., Boruch, K. (2009). Skutki kryzysu finansowego na rynek papierów wartościowych [Effects of the financial crisis on securities], [in:] T. Truskolaski, Przyczyny i skutki kryzysów finansowych we współczesnym świecie [Causes and effects of financial crises at present day], Wydawnictwo Uniwersytetu w Białymstoku, Białystok, 15-16.

Council Regulation (EU) No. 1096/2010 of 17 November 2010 conferring specific tasks upon the European Central Bank concerning the functioning of the European Systemic Risk Board, OJ L 331/15.12.2010.

Dettro, Ch. (2008). Fraud gone wild. Pyramid, Ponzi schemes disguised as valid investment opportunities, The state journal register, Springfield, Illinois, 23, 3 .

Directive of the European Parliament and of the Council (2011) amending Directives 2003/71/EC and 2009/138/EC in respect of the powers of the European Insurance and Occupational Pensions Authority and the European Securities and Markets Authority, Brussels 0006 (COD),19/01/2011.

Dunbar, J., Donald, D. (2009). The Roots of the Financial Crisis: Who Is to Blame?, The Center for Public Integrity, Washington, 05/06.

European System of Financial Supervision (ESFS). (2011). Polish Financial Supervision Authority, Warsaw, 1-4.

Goodhart, Ch. (2009). Kryzys finansowy i przyszłość systemu finansowego [The financial crisis and prospects for the financial system], BRE Bank S.A., CASE, Warsaw, 100, 15.

Index World Market Cup Bloomberg Finance 23/03/2011.

Kluza, K., Cholewiński, R. (2010). Wnioski z kryzysu w kontekście hipotezy niestabilności finansowej [Conclusions from the crisis in the context of hypothesis if financial instability], [in:] Przybylska-Kapuścińska, W. Handschke, J., Rynki finansowe i ubezpieczenia. Nowe perspektywy instytucji i instrumentów [Financial markets and insurances. New perspectives for institutions and instrument], Wydawnictwo Uniwersytetu Ekonomicznego w Poznaniu, Poznań, 34-35.

Mason, P. (2010). Finansowy kataklizm. Koniec wieku chciwości [Financial disaster. End of the age of avarice], Wydawnictwo Uniwersytetu Jagiellońskiego, Kraków, 07.

Mitręga-Niestrój, K. (2010). Komitet globalnego systemu finansowego i jego działania na rzecz zwiększenia stabilności światowego systemu finansowego [A Committee of the global financial system and its actions to enhance stability of world financial system], [in:] Żabińska, J. (ed.) Rola międzynarodowej współpracy finansowej w tworzeniu norm i regulacji ostrożnościowych zabezpieczających stabilność systemów finansowych [A role of international financial cooperation in establishing standards and prudential regulations which safeguard stability of financial systems], Wydawnictwo Akademii Ekonomicznej im. Karola Adamieckiego w Katowicach, Katowice, 43-44.

Raczyński, M. (2008). Implikacje konwergencji w branżach ICT dla polityki regulacyjnej [Implications of convergence in the ICT branches for regulation policy], Cracow University of Economics - listed a written version, Cracow, 195.

Regulation (EU) No. 1092/2010 of the European Parliament and of the Council of 24 November 2010 on European Union macro-prudential oversight of the financial system and establishing a European Systemic Risk Board, OJ L $331 / 1$ of 2010.

Regulation (EU) No. 1093/2010 of the European Parliament and of the Council of 24 November 2010 establishing a European Supervisory Authority (European Banking Authority), amending Decision No 716/2009/EC and repealing Commission Decision 2009/78/EC, OJ L 331/12 of 2010.

Regulation of the European Parliament and of the Council establishing a European Securities and Markets Authority, Brussels, COM 503 final (2009).

Ross, A. (2011). 22 Largest Bankruptcies in the World History, www.instantshift.com (April 5, 2011).

Sikorka, E., Wiatrak, P. (2011). Wybrane kryzysy finansowe końca XX wieku a obecny kryzys finansowy na świecie [Selected financial crises at the end of 20th century and the correct global financial crisis], SGH, Warsaw, 9-10.

Trends econometric models. (2010). International Labour Office, Switzerland, 10. 
Whallen, Ch. J. (2007). The US Credit Crunch of 2007. A Minsky Moment, The Levy Economics Institute of Bard College, Public Policy Brief, Annandale, 92.

White, L. H. (2007). Federal Reserve Policy and the Housing Bubble, Cato Journal, Vol. 29, No. 1, Cato Institute 2009 and A. Greenspan, The Roots of the Mortgage Crisis, Wall Street Journal (12 December 2007).

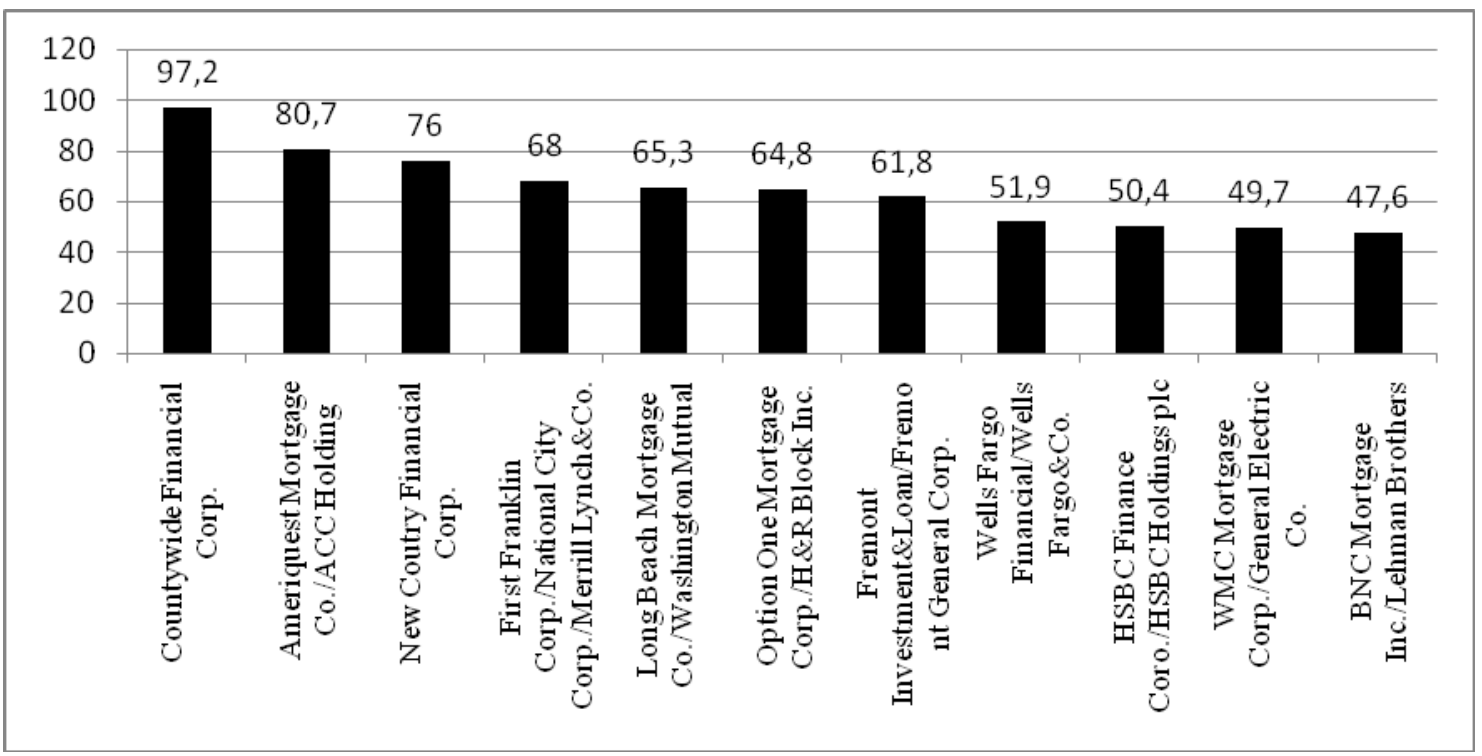

Figure 1. The value of subprime mortgages extended by the 11 largest subprime mortgage originators in the US in 1996-2006 (value over USD 31 billion). Given mortgages values rounded to the nearest value, adding to the last of the remaining digits by one, if the subsequent digit of the original number was $\geq 5$.

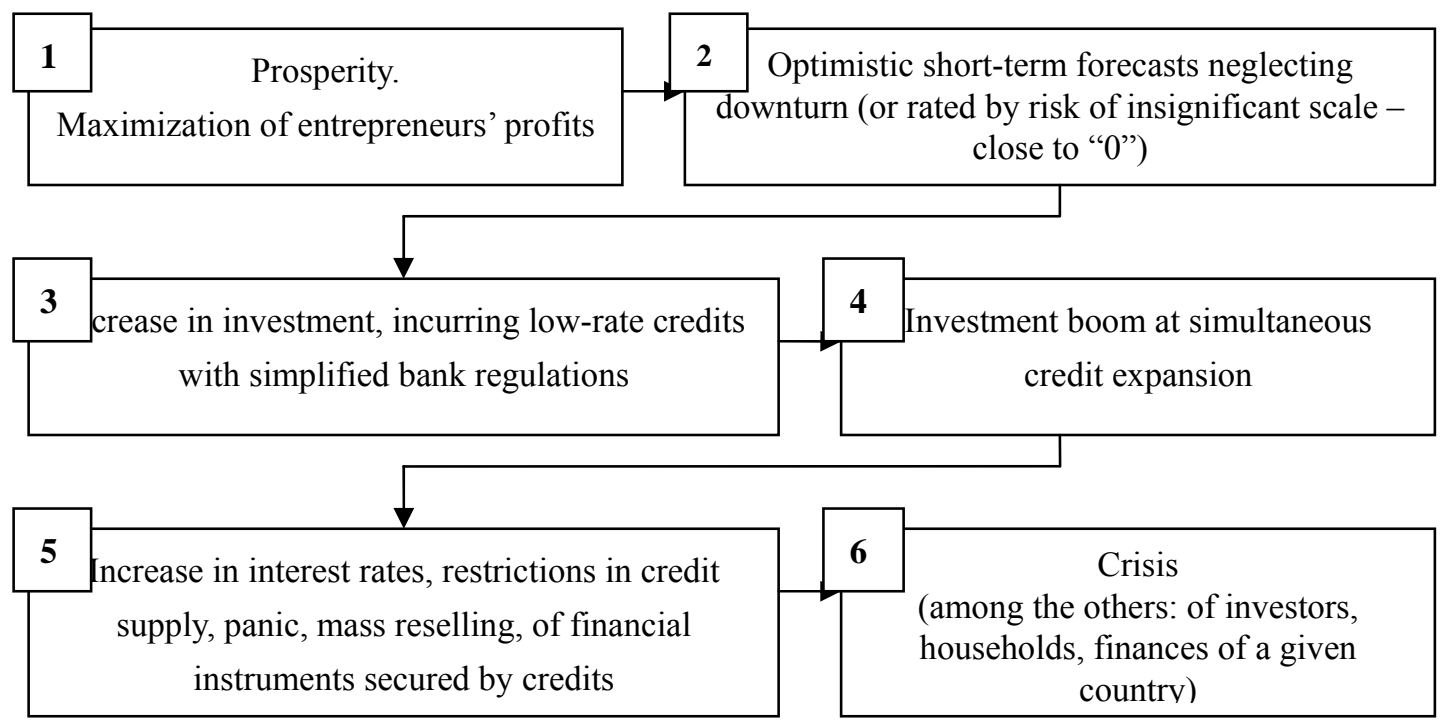

Figure 2. Functioning of economy according to Hyman Minsky's theory of financial instability.

Source: own study. 


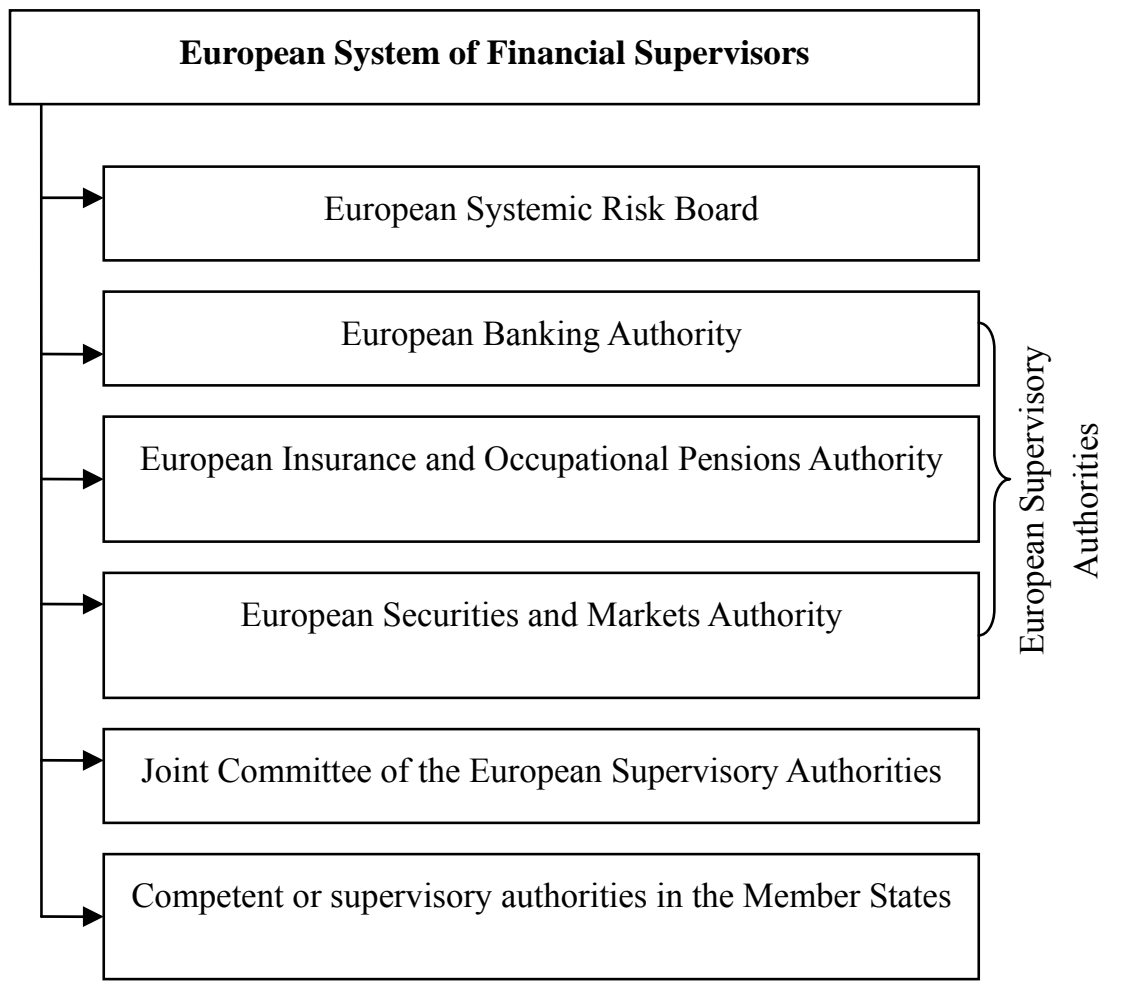

Figure 3. European System of Financial Supervision.

Source: own study on the basis of the Regulation No. 1092/2010 of the European Parliament and of the Council. 